\title{
Estimasi Sumberdaya Batugamping di PT X, Kecamatan Palimanan, Kabupaten Cirebon, Provinsi Jawa Barat
}

\section{Dika Hadi Anugrah*, Dono Guntoro}

\author{
Prodi Teknik Pertambangan, Fakultas Teknik, Universitas Islam \\ Bandung, Indonesia. \\ *dikahadianugrah@gmail.com, guntoro_mining@gmail.com
}

\begin{abstract}
Limestone is an excavated material that can be used as a raw material for cement. In the manufacture of cement there are three raw materials, namely limestone as the main raw material, then there are corrective raw materials, namely iron sand and quartz sand and additive raw material, namely gypsum. The main compound of limestone used as raw material for cement is $\mathrm{CaO}$ compound. In the formation of limestone, the value of $\mathrm{CaO}$ content has variations due to differences in facies in the formation process, so that the distribution of $\mathrm{CaO}$ content is not necessarily homogeneous. With the requirement for $\mathrm{CaO}$ content as a cement raw material, which is $47 \%$, it is necessary to have a model to describe the geometry of the sediment and the distribution of $\mathrm{CaO}$ levels at the research site. The resource estimation method used is the kriging method. The basis for determining resources is to talk about the level of confidence. Thus, the selection of the kriging method is because this method is the best linear unbiased estimator, many parameters are considered in the kriging method, one of which is the variogram model. The variogram model is a spatial statistical analysis (geostatistics), or statistical analysis by considering the location of the sample points, in order to obtain information related to the relationship of one point to another which is expressed in a range or radius of information points that still have a spatial relationship. The results of the estimation of limestone resources are as follows. Limestone resources in Quarry B are 12,844,500 tons with an average $\mathrm{CaO}$ content of $48.48 \%$, and in Quarry $\mathrm{C}$ as many as $10,857,000$ tons with an average $\mathrm{CaO}$ content of $41.17 \%$.
\end{abstract}

Keywords: Resources, Requirements for Cement Raw Materials, Limestone.

Abstrak. Batugamping merupakan bahan galian yang dapat dimanfaatkan salah satunya sebagai bahan baku semen. Dalam pembuatan semen terdapat tiga bahan baku, yaitu batugamping sebagai bahan baku utama, kemudian terdapat bahan baku corrective yaitu pasir besi dan pasir kuarsa serta bahan baku additive yaitu gypsum. Senyawa utama batugamping yang dimanfaatkan sebagai bahan baku semen adalah senyawa $\mathrm{CaO}$. Pada keterbentukan batugamping, nilai kadar $\mathrm{CaO}$ memiliki variasi yang diakibatkan adanya perbedaan fasies dalam proses pembentukannya, sehingga distribusi kadar $\mathrm{CaO}$ yang belum tentu homogen. Dengan adanya syarat kadar $\mathrm{CaO}$ sebagai bahan baku semen yaitu 47\% maka perlu adanya pemodelan untuk menggambarkan bentuk geometri endapan dan distribusi kadar $\mathrm{CaO}$ di lokasi penelitian. Metode estimasi sumberdaya yang digunakan adalah metode kriging. Dasar dalam penentuan sumberdaya adalah berbicara terkait tingkat keyakinan. Dengan demikian, pemilihan metode kriging dikarenakan metode ini merupakan best linear unbiased estimator, banyak parameter yang diperhatikan dalam metode kriging salah satunya adalah model variogram. Model variogram merupakan analisis statistik spasial (geostatistik), atau analisis statistik dengan mempertimbangkan lokasi titik sampel, sehingga didapatkan informasi terkait hubungan satu titik dengan titik yang lainnya yang dinyatakan dalam range atau radius titik informasi yang masih memiliki hubungan secara spasial. Hasil dari estimasi sumberdaya batugamping adalah sebagai berikut Sumberdaya batugamping di Quarry B sebanyak 12.844.500 Ton dengan kadar rata-rata $\mathrm{CaO}$ 48,48\%, dan di Quarry C sebanyak 10.857.000 Ton dengan kadar rata-rata $\mathrm{CaO}$ 41,17\%.

Kata Kunci: Sumberdaya, Syarat Bahan Baku Semen, Batugamping. 


\section{A. Pendahuluan}

Sumberdaya merupakan suatu konsentrasi atau keterbentukan dari material yang memiliki nilai ekonomis pada atau di atas kerak bumi dengan bentuk, kualitas dan kuantitas tertentu yang memiliki keprospekan yang beralasan untuk pada akhirnya dapat diekstrak secara ekonomis (KCMI, 2017). Berdasarkan profil data dan statistik energi dan sumberdaya mineral Jawa Barat, di Kabupaten Cirebon terdapat sumberdaya batugamping sebanyak 177.891.333 ton.

Batugamping merupakan bahan galian yang dapat dimanfaatkan salah satunya sebagai bahan baku semen. Semen merupakan suatu bahan hidrolis, yaitu bahan yang akan mengalami proses pengerasan pada pencampurannya dengan air ataupun dengan larutan asam. Dalam pembuatan semen terdapat tiga bahan baku, yaitu batugamping sebagai bahan baku utama, kemudian terdapat bahan baku corrective yaitu pasir besi dan pasir kuarsa serta bahan baku additive yaitu gypsum. Senyawa utama batugamping yang dimanfaatkan sebagai bahan baku semen adalah senyawa $\mathrm{CaO}$.

Pada keterbentukan batugamping, nilai kadar $\mathrm{CaO}$ memiliki variasi yang diakibatkan adanya perbedaan fasies dalam proses pembentukannya. Dengan adanya variabilitas antara spasial terhadap kadar $\mathrm{CaO}$ di alam, sehingga distribusinya belum tentu homogen, dengan demikian perlu adanya pemodelan dan estimasi sumberdaya untuk mendapatkan distribusi kadar $\mathrm{CaO}$. Pada dasarnya pemodelan dan estimasi sumberdaya bertujuan untuk mengetahui kuantitas dan distribusi kualitas batugamping. Dengan adanya nilai syarat kadar $\mathrm{CaO}$ sebagai bahan baku semen yang telah ditentukan perusahaan yaitu 47\%, maka pemodelan dan estimasi sumberdaya ini sangat penting sehingga didapatkan model blok sumberdaya dengan berdasarkan kualitasnya yaitu kadar $\mathrm{CaO}$.

\section{B. Metodologi Penelitian}

Metode penelitian yang digunakan dalam penelitian ini yaitu dengan cara pengambilan data ke perusahaan serta pengolahan data sehingga dapat dihasilkan suatu analisis dari kegiatan pengukuran, dan pengolahan. Data yang didapatkan dari metode yang dilakukan antara lain :

1. Pengambilan Data

Dalam penelitian ini, data yang digunakan berupa data sekunder hasil dari kegiatan pengeboran di PT X, meliputi data survey, data collar, data litologi dan data assay. Selain itu terdapat data sekunder lainnya yang berasal dari perusahaan seperti peta topografi dan peta geologi lokal.

2. Pengolahan Data

Data yang digunakan dalam mengestimasi sumberdaya antara lain data survey, data collar, data litologi dan data assay kemudian terlebih dahulu dilakukan validasi dan preparasi data, kemudian dilakukan analisis statistik untuk mendapatkan distribusi data sebagai penentuan jenis kriging yang akan digunakan. Data hasil uji laboratorium atau data assay kemudian dilakukan composite setiap 6 meter (dengan pertimbangan tinggi jenjang), kemudian data yang telah dilakukan composite dilakukan cut outlier, pemotongan pencilan tersebut dilakukan untuk menghindari underestimate dan overestimate pada saat pembuatan model variogram. Sebelum memodelkan variogram, terlebih dahulu membuat variogram map, yaitu bertujuan untuk mendapatkan arah yang memiliki nilai yang stasioner sehingga mendapatkan output variogram eksperimental, kemudian pemodelan variogram dilakukan untuk mendapatkan parameter sebagai input dalam mengestimasi sumberdaya, setelah didapatkan model variogram, kemudian model variogram tersebut terlebih dahulu divalidasi terhadap grade (raw data). Sebelum mengestimasi sumberdaya, terlebih dahulu membuat blok-blok yang akan diestimasi, kemudian estimasi sumberdaya dilakukan dengan memasukan parameter hasil dari model variogram hingga mendapatkan model sumberdaya. Model sumberdaya kemudian divalidasi terhadap topografi dan diklasifikasikan berdasarkan kandungan $\mathrm{CaO}$ yang telah ditetapkan oleh perusahaan, sehingga didapatkan nilai sumberdaya batugamping yang memenuhi dan tidak memenuhi cut off grade kadar $\mathrm{CaO}$.

3. Teknik Analisis Data

Teknik analisis data menggunakan metode analisis statistik yaitu analisis univariate. 
Hasil analisis tersebut berupa nilai variance yang akan menjadi input untuk fitting variogram dan distribusi data digunakan untuk menentukan metode kriging yang akan digunakan untuk memodelkan sumberdaya, sehingga setelah melewati proses estimasi kriging, jenis sumberdaya bisa didapatkan dengan menghitung nilai RKSD.

4. Kesimpulan

Bab ini berisikan kesimpulan yang telah didapatkan dari proses pengolahan data yang dilakukan selama skripsi dilakukan, sekaligus memberikan saran untuk kemudian dapat menjadi evaluasi dalam proses pengambilan data di kemudian hari agar lebih baik.

\section{Hasil Penelitian dan Pembahasan}

\section{Data Hasil Penelitian}

Hasil dari tahapan mengestimasi sumberdaya adalah sebagai berikut:

1. Analisis Statistik

Dalam penelitian ini terdapat dua analisis statistik yaitu analisis univariate dan analisis bivariate, termasuk di dalamnya terdapat uji normalitas baik itu secara visual (Histogram dan PP-Plot). Adapun analisis deskriptif terhadap kadar $\mathrm{CaO}$ memiliki nilai koefisien variasi sebesar 0,26 di Quarry B dan 0,33 di Quarry C. jika dilihat berdasarkan nilai koefisien variasi pada beberapa tipe endapan mineral di dunia, koefisien variasi $\mathrm{CaO}$ pada daerah penelitian lebih cenderung mendekati nilai koefisien variasi endapan iron ore $(0,27)$ yang menandakan bahwa penyebaran kadar $\mathrm{CaO}$ di lokasi penelitian tidak homogen.

\begin{tabular}{lrr}
\hline \multirow{1}{*}{ Statistik } & \multicolumn{2}{c}{$\mathrm{CaO}$} \\
\cline { 2 - 3 } & Quarry B & Quarry C \\
\hline Mean & 45.281606 & 37.178361 \\
Standard Error & 0.3987699 & 0.3641645 \\
Median & 49.35 & 40.649 \\
Mode & 55.52 & 30.87 \\
Standard Deviation & 11.963098 & 12.456342 \\
Sample Variance & 143.11572 & 155.16045 \\
Kurtosis & 3.21336 & 1.2568974 \\
& & \\
Skewness & 1.9681819 & 1.3638068 \\
Range & 53.769 & 52.86 \\
Minimum & 2.251 & 2.065 \\
Maximum & 56.02 & 54.925 \\
Sum & 90753.445 & 43498.682 \\
Count & 900 & 1170 \\
Koefisien Variasi & 0.2641933 & 0.3350428 \\
\hline
\end{tabular}

Kemudian dilakukan uji normalitas secara visual dengan membuat histogram, karena 
histogram sangat berguna untuk mengetahui bentuk secara grafik dari distribusi suatu data, sehingga dapat berguna sebagai informasi awal untuk melakukan pemrograman data dengan arti lain, kesimpulan dari hasil uji statistik ini dapat menentukan jenis kriging yang tepat untuk digunakan berdasarkan distribusi data di lokasi penelitian, jika distribusi data tidak normal, jenis kriging yang digunakan yaitu ordinary kriging dan jika distribusi data normal, maka kriging yang digunakan adalah simple kriging. Analisis univariate bertujuan untuk mendapatkan informasi mengenai distribusi data, karena dalam penelitian ini variabel distribusi data akan menentukan metode kriging yang akan digunakan. Dalam penelitian ini variabel senyawa yang dianalisis yaitu senyawa $\mathrm{CaO}$. Jika dilihat pada histogram, distribusi data kadar $\mathrm{CaO}$ menunjukkan distribusi skewness negative, hal tersebut mengartikan bahwa distribusi kadar $\mathrm{CaO}$ di lokasi penelitian tidak homogen.
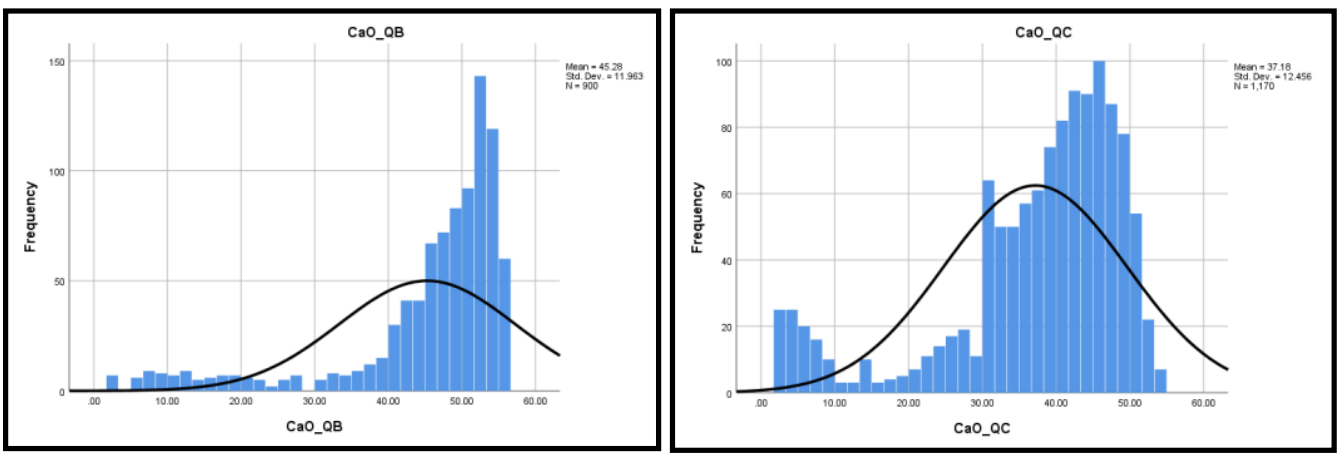

Probability plot merupakan suatu cara pada uji normalitas secara grafik untuk mendapatkan informasi bahwa data tersebar secara normal atau tidak normal, karena seperti pada histogram, informasi terkait distribusi data sangat mempengaruhi proses pengerjaan estimasi dengan geostatistik, karena akan menentukan jenis metode kriging yang akan digunakan. Jika titik tersebar merata di sekitar garis linear dengan sudut $45^{\circ}$ maka data terdistribusi normal, jika tidak maka data tidak terdistribusi normal. Kemudian jika dilihat dari Probability plot menunjukkan titik-titik tidak tersebar searah garis linear yang ada, sehingga data memiliki distribusi tidak normal. Sama halnya dengan kesimpulan terhadap histogram, yaitu distribusi kadar $\mathrm{CaO}$ di lokasi penelitian tidak homogen. Jadi dapat disimpulkan bahwa kadar $\mathrm{CaO}$ memiliki distribusi data tidak normal sehingga metode yang akan digunakan adalah ordinary kriging.
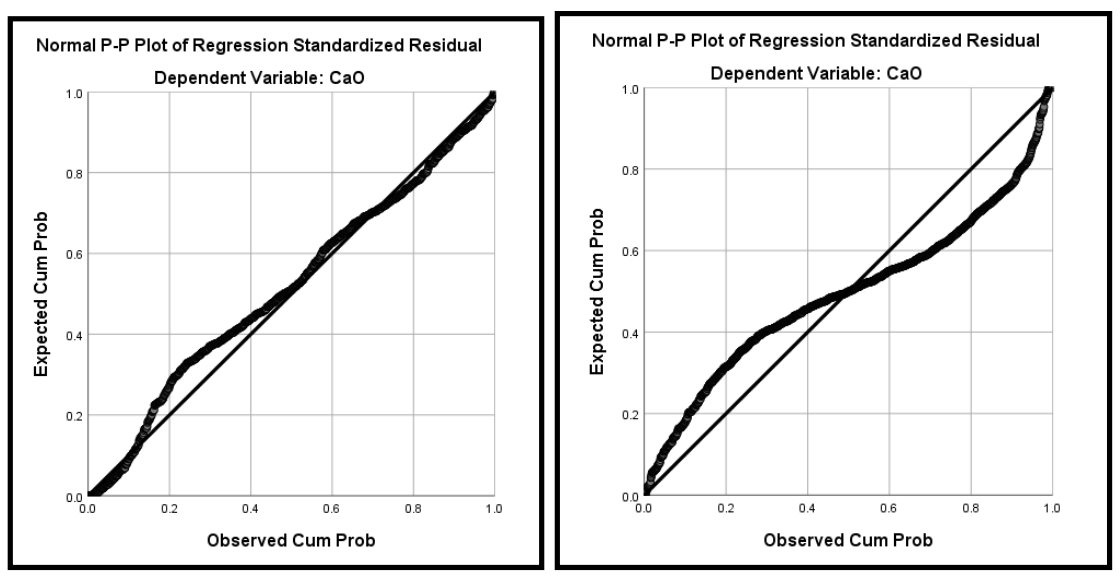

Section 1 ini dengan pemodelan slide menunjukan nilai Faktor Keamanan 0,932 dengan nilai PF (Probability Failure) 95\%, dengan beban yang ditambah dari nilai beban beton dan kegempaan pada section 1 ini menunjukan lereng yang memiliki nilai Faktor Keamanan $\leq 1,2$. 


\section{Model Geologi dan Estimasi Sumberdaya}

Dalam menentukan model sumberdaya sebagai tahap dalam mengestimasi kadar $\mathrm{CaO}$ dilakukan interpretasi terhadap data litologi hasil dari data pengeboran terlebih dahulu, agar dapat mendapatkan informasi terkait bentuk penyebaran batugamping di daerah penelitian. Pada pemodelan geologi ini, data yang digunakan merupakan data hasil dari deskripsi megaskopis terhadap sampel core di lapangan, dan pada penentuan jenis ukuran butir pun hanya dibatasi terhadap deskripsi dengan bantuan komparator, tidak dilakukan uji fraksi.

Dari hasil deskripsi core yang telah dilakukan, sebagaimana dapat dilihat pada lampiran $\log$ bor, di daerah penelitian terdapat susunan batugamping dengan memiliki sisipan-sisipan lempung dan pasir. Terdapatnya material ukuran lempung dan pasir pada batugamping disebabkan pada saat keterbentukan batugamping itu sendiri, karena batugamping ketika terbentuk tidak semua tersusun oleh fosil binatang laut saja, akan tetapi terdapat juga endapan sedimenter yang berasal dari daratan yang mengendap bersama.
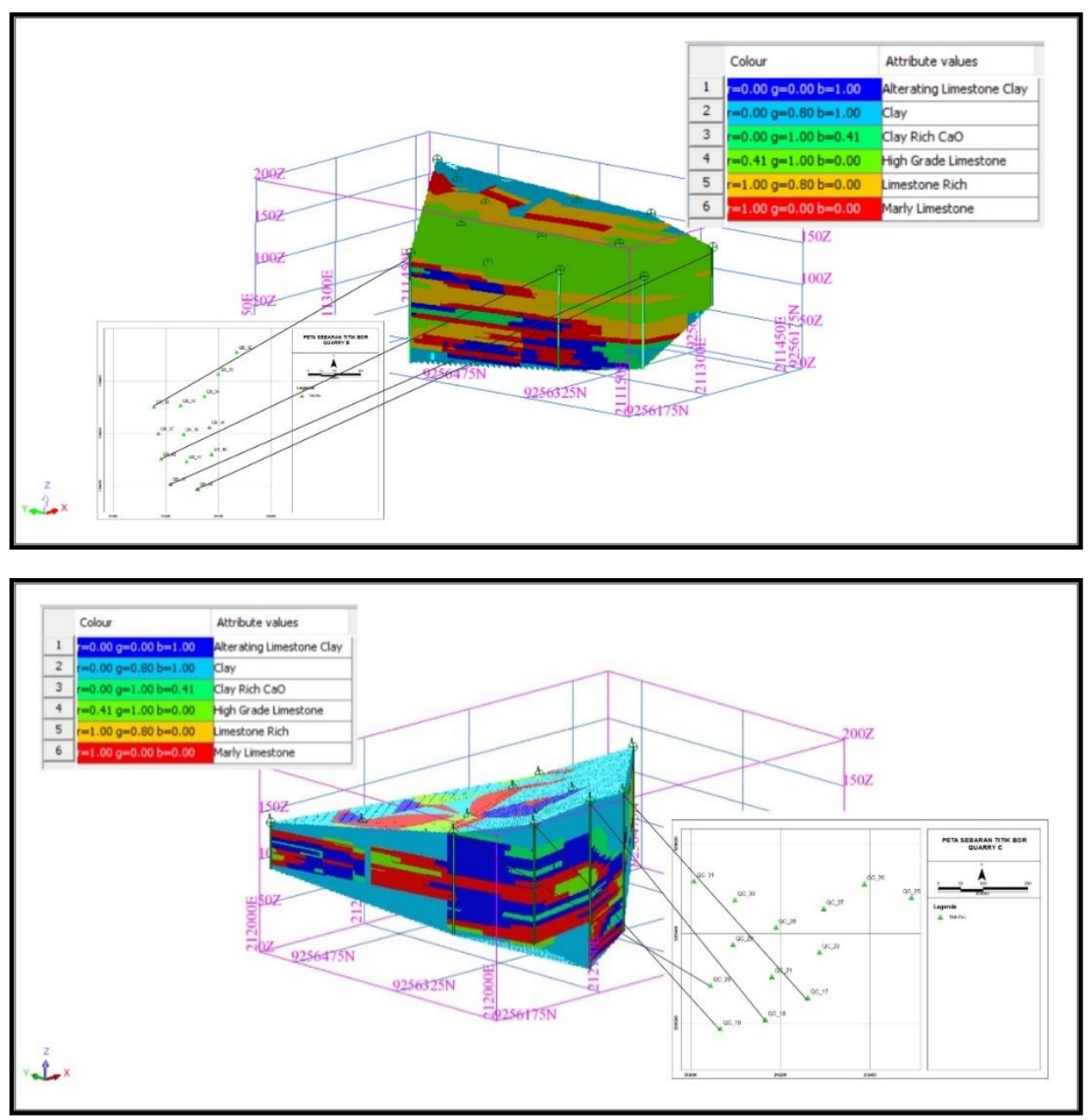

Dari hasil pemodelan geologi terhadap data hasil proses validasi antara data deskripsi megaskopis dengan data kadar hasil pengujian laboratorium di Quarry B dan Quarry C didapatkan litologi antara lain clay, clay rich $\mathrm{CaO}$, alterating limestone clay, marly limestone, limestone rich dan high grade limestone. Secara keterbentukan, batugamping terbentuk dari susunan fosil-fosil binatang laut dangkal, masing-masing fosil yang menyusun batugamping menyebabkan perbedaan dalam karakteristiknya, sehingga secara fisik dan kimia batugamping memiliki perbedaan walaupun tidak signifikan.

Dari hasil pemodelan geologi, di daerah penelitian bentuk masing-masing litologi memiliki bentuk seperti lensa dan menjari, hal tersebut dapat mengindikasikan beberapa hal, seperti indikasi jenis fosil berbeda-beda pada satu pengendapan. Kemudian jika dilihat pada 
model geologi, dapat diindikasikan lingkungan pengendapan batugamping di daerah penelitian berada pada reef core hingga back reef lagoon, karena memiliki perbedaan antar litologinya dan memiliki bentuk lensa dan menjari.

\begin{tabular}{|c|c|c|c|c|c|c|}
\hline No & Klasifikasi Litologi & $\begin{array}{l}\text { Volume } \\
\left(\mathrm{m}^{3}\right)\end{array}$ & $\begin{array}{l}\text { Density } \\
\left(\text { ton } / \mathrm{m}^{3}\right)\end{array}$ & $\begin{array}{c}\text { Tonase } \\
\text { (ton) }\end{array}$ & $\begin{array}{c}\text { Kadar } \\
\mathrm{CaO}(\%)\end{array}$ & $\begin{array}{c}\text { Tonase } \\
\mathrm{CaO} \text { (ton) }\end{array}$ \\
\hline 1 & High Grade Limestone & 2.850 .000 & 2,55 & 7.267 .500 & 51,34 & $3.731 .134,5$ \\
\hline 2 & Limestone Rich $\mathrm{CaO}$ & 1.620 .000 & 2,2 & 3.564 .000 & 46,88 & $1.670 .803,2$ \\
\hline 3 & Marly Limestone & 660.000 & 2,2 & 1.452 .000 & 42,33 & $614.631,6$ \\
\hline 4 & $\begin{array}{l}\text { Alterating Limestone } \\
\text { Clay }\end{array}$ & 255.000 & 2,2 & 561.000 & 37,57 & $210.767,7$ \\
\hline 5 & Clay Rich $\mathrm{CaO}$ & 210.000 & 2,1 & 441.000 & 33,18 & $146.323,8$ \\
\hline 6 & Clay & 270.000 & 1,9 & 513.000 & 4,82 & $24.726,6$ \\
\hline No & Klasifikasi Litologi & $\begin{array}{l}\text { Volume } \\
\qquad\left(\mathrm{m}^{3}\right)\end{array}$ & $\begin{array}{l}\text { Density } \\
\left(\text { ton } / \mathrm{m}^{3}\right)\end{array}$ & $\begin{array}{l}\text { Tonase } \\
\text { (ton) }\end{array}$ & $\begin{array}{c}\text { Kadar } \\
\mathrm{CaO}(\%)\end{array}$ & $\begin{array}{c}\text { Tonase } \\
\mathrm{CaO} \text { (ton) }\end{array}$ \\
\hline 1 & $\begin{array}{l}\text { High Grade } \\
\text { Limestone }\end{array}$ & 0 & 2,55 & 0 & 0 & 0 \\
\hline 2 & Limestone Rich $\mathrm{CaO}$ & 1.890 .000 & 2,2 & 4.158 .000 & 42,08 & $1.749 .686,4$ \\
\hline 3 & Marly Limestone & 1.155 .000 & 2,2 & 2.541 .000 & 45,54 & $1.157 .171,4$ \\
\hline 4 & $\begin{array}{l}\text { Alterating Limestone } \\
\text { Clay }\end{array}$ & 1.890 .000 & 2,2 & 4.158 .000 & 37,59 & $1.562 .992,2$ \\
\hline 5 & Clay Rich $\mathrm{CaO}$ & 1.005 .000 & 2,1 & 2.110 .500 & 32,85 & $693.299,25$ \\
\hline 6 & Clay & 2.040 .000 & 1,9 & 3.876 .000 & 6,9 & 267.444 \\
\hline
\end{tabular}

\section{Kesimpulan}

Adapun kesimpulan yang dapat diperoleh berdasarkan penelitian yang telah dilakukan antara lain :

1. Berdasarkan analisis statistik, Quarry B dan Quarry C memiliki distribusi data tidak normal, dengan nilai koefisien variasi 0,26 dan 0,33. Hasil dari pembuatan peta isopach di Quarry B memiliki arah distribusi total tebal relatif homogen ke arah kuadran 1 dan kuadran 3, dan semakin menebal ke arah Barat Laut. Begitupun di Quarry C, distrisbusi homogen ke arah kuadran 1 dan kuadran 3 atau ke arah Timur Laut dan Barat Daya, semakin menebal ke arah Tenggara;

2. Untuk batas bawah kadar $\mathrm{CaO}$ yang masih bisa digunakan sebagai bahan baku semen adalah $37,98 \%$;

3. Sumberdaya batugamping di Quarry B sebanyak 12.844.500 Ton dengan kadar rata-rata $\mathrm{CaO} 48,48 \%$, dan di Quarry C sebanyak 10.857.000 Ton dengan kadar rata-rata $\mathrm{CaO}$ 
$41,17 \%$.

\section{Acknowledge}

1. Dosen dan Staff Prodi Teknik Pertambangan Universitas Islam Bandung. kepada Bapak Dr. Ir. Yunus Ashari, M.T. selaku Ketua Prodi, Bapak Noor Fauzi Isniarno, S.Si.,S.Pd., M.T. selaku Sekretaris Prodi, Bapak Ir. Dono Guntoro S.T, M.T. selaku Pembimbing, Bapak Dr. Ir. Yunus Ashari, M.T, selaku Co-Pembimbing serta semua Dosen dan Staf yang senantisa memberikan do'a, dukungan, motivasi kepada penyusun

2. Orang Tua dan Keluarga Penulis, Kedua Orangtua, Agus Gunawan dan Ai Haryati, terimakasih selalu memberikan dukungan terbaik.

3. Staff Asisten Laboratorium Eksplorasi Unisba.

4. Keluarga Besar Tambang 2017, terimakasih karena tidak pernah lelah membantu dan berjuang bersama serta support terbaik yang diberikan. Kalian semua Orang Orang Hebat

\section{Daftar Pustaka}

[1] Armstrong, M., 1998. "Basic Linear Geostatistics". Springer-Verlag Berlin Heidelberg. New York.

[2] Badan Standarisasi Nasional., 2015. SNI-15-2039-2015 Semen Portland. Jakarta: Badan Standarisasi Nasional.

[3] Boudagher-Fadel, M.K., 2008. "Evolution and Geological Significance of Larger Ben-thicForaminifera, Developments in Palaeontology and Stratigraphy". Vol. 21. Elsevier, Amsterdam, 544.

[4] Scoffin, T.P., 1987 "An Introduction to Carbonate Sediment and Rocks". Blackie and Son Ltd, London, UK.

[5] David, M., 1977. "Geostatistical Ore Reserve Estimation”. Elsevier Scientific Publishing Company, Amsterdam.

[6] Farhan, Irsan., 2019. "Analisis Penyebaran Batugamping Berdasarkan Kualitas Lime Saturation Factor di PT X. Palimanan, Cirebon, Jawa Barat". Jurnal Fakultas Teknik Kebumian dan Energi Universitas Trisakti : Jakarta Barat.

[7] Farhan, Mohammad. 2017. "Statistik Nonparametrik Terapan". Yogyakarta : Andi.

[8] Fitria, Nurul., 2012. "Identifikasi dan Karakterisasi Batu Kapur Tuban untuk Pengembangan Produk CaCO3" . eJournal Institut Teknologi Sepuluh Nopember Surabaya.

[9] Gusman, Mulya., 2009, "Estimasi Sumberdaya Batugamping dengan Metode Kriging Blok 3 Dimensi Studi Kasus : Endapan Batugamping PT Semen Padang”. Bandung : Perpustakaan Digital ITB.

[10] Heriawan, M. N., 2019. "Bahan Ajar TA5.212-Geostatistik Terapan". Program Studi Magister Rekayasa Pertambangan. ITB. Bandung. 